\title{
Theological remarks on the Accra Confession
}

\section{Author:}

Hans-Wilfried Haase

\section{Affiliation: \\ ${ }^{1}$ Evangelical Reformed \\ Church, Lüneburg, \\ Germany}

\section{Correspondence to:}

Allan A. Boesak

e-mail:

boesak@mweb.co.za

\section{Postal address:}

Postnet Suite 285, Private

Bag X15, Somerset West

7130, South Africa

\section{Keywords:}

Accra confession; theology and the developing world; league of justice; Africa; global ethics

\section{Dates:}

Received: 21 Aug. 2008

Accepted: 10 June 2009

Published: 06 Nov. 2009

How to cite this article:

Haase, H-W., 2009,

'Theological remarks on the Accra Confession', HTS Teologiese Studies/ Theological Studies 65(1), Art. \#281, 3 pages. DOI: 10.4102/hts.v65i1.281

\section{This article is available} at: http://www.hts.org.za

\section{Note:}

Paper presented at a meeting of the Joint Globalization Task Team of the Reformed Churches of Germany and South Africa, held at Arnoldsheim, Frankfurt, Germany, 26-30 May 2008.

\section{(c) 2009. The Authors.} Licensee: OpenJournals Publishing. This work is licensed under the Creative Commons Attribution License.

\section{ABSTRACT}

This article provides a critical evaluation of the Accra Confession (WARC 2004). The misery in various regions of the southern hemisphere poses an extreme ethical challenge for the Christian faith; the outcry for justice should not be left unheeded. It is necessary that the causes of this misery should be clearly described before viable strategies for overcoming it can be developed. The Accra Confession seems to be rather one-dimensional in its evaluation of reality. The ethical charge implied by the term 'confession' is of little use when dealing with complex global fields of action that only rarely allow a simple equation of cause and reaction. It is not so much a 'confession' (or Bekenntnis) that is needed but rather a renewed discussion among all concerned on the best ways to achieve more justice.

\section{INTRODUCTION: CONFESSION?}

The Accra Confession (2004) raises fundamental theological questions. An evaluation of the importance and impact of the document has yet to be done. The theological status of the Accra Confession is unclear. It is partly a language problem, and there are also problems with the content. In AngloAmerican language usage, several terms are available to differentiate between the various aspects of 'confession'. In the German language the same term, Bekenntnis, is used for all aspects of confession, although not meant in the classical theological sense of the word. It has also been pointed out, and rightly so, that the World Alliance of Reformed Churches does not have the mandate to draw up such a 'classical confession'.

What then is intended by this term? It builds on the Reformed tradition, which differs from the Lutheran understanding of confession in some respects. The Reformed emphasis is on the actual act of confessing rather than on defining a doctrine. A confession is therefore open to be altered and supplemented in future (e.g. The Theological Declaration of Barmen 1934). Ethical questions can be included in a confession as was the case in the ethical discussions on peace (e.g. the status confessionis in the face of nuclear threat). Recently, the term processus confessionis has been introduced in order to express the ongoing character of decision-making, which constantly has to react to changing challenges.

In the Accra Confession faith-orientated action is the focus. The introduction and the first section already point out that conditions described as 'unbearable' have to be changed. The final section proposes that a 'league of justice' should be formed.

The question is why this document is called a 'confession'? The reason is ostensibly that it appeals to a similar kind of obligation in action as one would find in the area of doctrine. The term 'confession' appeals to a basic ecclesiastical consensus in the area of action.

This particular use of language within the Reformed circle should be examined for the sake of theological communication with others in the ecumenical movement. Ethical norms, once put into practice, can never be as unambiguous as dogmatic propositions. There can be a strong appeal for love and justice, but how they should be put into practice cannot be specified precisely or made obligatory. An extreme example is the role of Bonhoeffer in the resistance against Hitler which resulted in an ethical conflict: was the assassination of Hitler a 'responsible act'?

The Theological Declaration of Barmen allocated the function of reminding people of the Kingdom of God and its justice to the church. The concrete political transformation has, however, been left to the state.

In my opinion the Accra Confession addresses exactly this issue of a lack of clarity and general obligation in the area of practical action. One reason for the lack of clarity and general consensus on what actions to take is that, for the sake of the greater objectives, compromise is necessary. Another reason is that, when it comes to motivation, there is the issue of intention and secondary intention. An example: Duke Ernst von Braunschweig-Lüneburg was a pious man. For the sake of his convictions he introduced the Reformation in his duchy. He was called Ernst the Confessor. Simultaneous to introducing the Reformation he also rehabilitated public finance. Another issue concerning intention is that even the best intentions do not rule out the possibility of error which could have disastrous results.

It furthermore becomes extremely difficult when ethical problems have a certain degree of complexity and the areas of action have become impossibly broad. In the area of global action (what does that mean ethically?) an incalculable number of factors play a role. A simple allocation of cause and effect is hardly possible. Who is responsible for what? Who really has the power to achieve some precise goal or other? Global systems rather remind of the functioning of very sophisticated mobiles. If one part is pushed in the required direction, the positions of other parts will be affected. Such side-effects can be most undesirable. Who would then be responsible? 
Dogmatic propositions have the advantage that they also take into account what is not being achieved. For example, they include the sin and fallibility of humanity. God's actions speak to the actions and non-action, the successes and failures of human beings.

\section{DESCRIPTION OF THE SITUATION}

\section{Inadequate analysis}

The Accra Declaration is firmly anchored in the context of African reality. It reflects the misery that prevails in various regions of the southern hemisphere and especially in Africa. It can be understood as an outcry that draws attention to the dire need of people and demands effective solutions. This outcry for justice should not remain unheeded. The present situation constitutes an extreme ethical challenge for the Christian faith. Though practical solutions are sorely needed, Christians are not exempt from continuing to dialogue in order to come to a reasonable and comprehensive description of the causes of the misery as well as possible strategies to overcome it. Unfortunately, the picture of reality painted by the Accra Declaration is rather rough, one-dimensional and simplistic This could get in the way of finding effective solutions for justice.

The Accra Declaration seems to have the intention of analysing the situation ('to recognise the signs of the time'), but in fact reaches its conclusions before the analysis has begun. There is no lack of precautionary clauses such as (par. 11): 'We recognise the complexity of this situation and do not seek simple answers'. In actual fact, however, it rather simply attributes all the misery in the world to neoliberal economic globalisation.

\section{Inadequate differentiation}

As far as the description of the world economy is concerned the Accra Declaration does not differentiate between vastly dissimilar realities. The fact that the market economies in Russia and China, in Sweden and Germany, in Dubai and Mexico have different faces, is not explored. The reality of a 'social economy' and the increasing ecological legislation in many countries are not taken into account. Also the fact that there are segments within the capitalistic economic order that are largely excluded from the market economy is not acknowledged. Examples of this in Europe are the public health service and agriculture. It is rather ironic that European agriculture, which has been subsidised and regulated by the state, which in turn drastically reduces the chances of many southern countries gaining access to the market, actually finds itself outside of the processes of a market economy.

\section{Imprecise terms}

Along the same lines an imprecise and provoking term such as 'empire' is used (par. 11) as a description for a 'concentration of economic, cultural, political and military power to a system of rule, under the leadership of powerful nations that want to protect and defend their own interests'. Who or what is accused of 'empirism' here? Such a term has no value in a precise analysis. Every time it is used it begs an interpreter to explain where 'the empire has struck again'. Such a term can be used at will as a metaphor for suspicion.

\section{The concept 'neo-liberalism'}

This article directs itself with uncompromising disapprobation against the so-called 'neo-liberalism'. By means of this term the Accra Declaration portrays various manifestations of 'untamed capitalism'. In other instances, however, this term becomes a caricature by its non-differentiation. The main difficulty is that no indication is given of what a just economic order would look like. What is supposed to take the place of 'the empire'? Here, the Accra Declaration remains unclear. Nevertheless, a subliminal affinity for a socialist economic system can be sensed throughout the document. Next to the present economic order, the Accra Declaration only directly disapproves of the 'Model of absolute planned economy' (par. 18). This is referred to only once. Given the historical failure of the planned economy with its waste of human goods and labour and its disastrous effect on the ecology, some discussion on this topic would have been expected.

\section{Total rejection of the present system}

The difficulty one has with the Declaration of Accra is that it fundamentally and uncompromisingly rejects the present economic system. However, it is practically impossible to step out of the existing system to which we all belong. It is only possible to gradually transform it. A good start could be installing social and ecological standards within a system of international regulations. Global institutions that regulate world trade and financial markets cannot be summarily eliminated in order to achieve this aim. These institutions should be changed through a gradual process. However, no realistic proposals to this effect are to be found in the Accra Declaration.

\section{One-dimensional perception}

'Economisation of the world' is the main reproach of the Accra Declaration. The document comments on the reality of the world as though only one dimension exists, namely the economic. Almost all evil is related to economic factors. Political factors such as good governance, democracy, freedom of the media as well as tolerance and reconciliation between cultures, peoples and religions play no part whatsoever. In actual fact, the absence of peace and a well-functioning government which sees to the effective levying of taxes, justice, the separation of powers and public order, seem to be the main reasons for the economic downturn in many societies. No attempt is made to explain why different countries have developed so diversely in spite of being subjected to the same general global political situation.

\section{POSSIBILITIES FOR ACTION}

The Accra Declaration tackles the basic issues of the current ethical discussion. Classical theological ethics focuses on individuals within the context of their lives and work. The individual is encouraged to live responsibly before God and together with humanity.

'What shall we do?' the people ask in response to the rather juridical sermon of John the Baptist (Luke 3:10). The directives are the following: The tax collectors should not take more than is permitted; the soldiers should be satisfied with their wages; whoever has two shirts should give one to him who has none. John's answer pertains to social ethics, which is also of great importance to Martin Luther. People ask what good they should do as a citizen or a servant, a prince or a soldier or a craftsman? On the one hand the social roles are predetermined. On the other hand social roles outline the individual area of responsibility.

The ethical argumentation becomes complicated when more complex contexts are scrutinised. Zwingli does this when he asks whether extortionate interest rates should be permitted. The answer is no, because people should give voluntarily to fellow Christians in need and should expect no reward. Therefore, citizens and Christians should also work actively to ensure that the authorities pass appropriate laws. If the authorities fail to do so, the citizens and Christians should accept this injustice. In this simple legalistic argumentation, the problem of institutional order and its material constraints comes into view.

Nowadays, in the context of globalisation, a highly complex system of international institutions, orders, mechanisms and treaties poses new challenges to ethics. As has always been the case, these matters should be argued from the perspective of individual ethics. This is indeed what the Accra Declaration does. The conscience of the individual is called upon when it comes to matters such as consumerism, greed for profit, lifestyle and ecologically responsible behaviour. 
Macro-social issues are more complicated, especially where global institutions are concerned. While following major principles with no intention of causing harm, the actions of such institutions sometimes have fatal consequences in particular cases. As they keep their focus on broader objectives, casualties along the way simply have to be accepted.

Systems such as the world economic order have no conscience that could be ethically addressed. There is no particular acting subject who could be held accountable. The Accra Declaration has pointed out that such systems function as ethically neutral mechanisms. Nevertheless, in terms of consequences they are of dramatic significance for the lives of billions of people. They are therefore anything but ethically neutral. They should be controlled, assessed, and where necessary, changed.

On the level of the state such assessment and change do take place continually, but on the global level only unsatisfactory political, legal or institutional steering mechanisms exist. This restricts the scope of ethical action considerably. For the sake of broader ethical objectives such as justice, peace or ecological sustainability, effective steering mechanisms should be developed on a global scale.

The main problem of the Accra Declaration is that it does not apply itself to this incomplete task, but exhausts itself with rhetoric largely borrowed from the field of individual ethics. 'What draws us together is the common effort for economic and ecological justice...'. That sounds good, but will accomplish little.

The Accra Declaration nevertheless makes an important contribution to the discussion on the ethical consequences of globalisation. It forcefully reminds us that the distress of a big part of humanity presents a challenge to the Christian faith. It calls for churches to act together, but what political and economic actions should be taken in order to bring about justice is still unclear. This matter of appropriate and effective action should be discussed in earnest. It becomes a problem, however, when some possible actions take on the quality of a confession and people who, for various reasons cannot agree with those actions, are then excluded from the confession. 